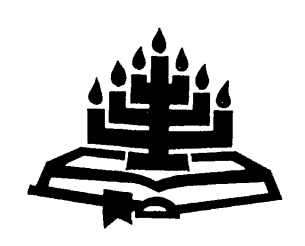

\title{
Die imago Dei in protologiese, Christologiese en eskatologiese perspektief
}

\author{
N. Vorster \\ Eenheid vir Reformatoriese Teologie \\ Potchefstroomkampus \\ Noordwes-Universiteit \\ POTCHEFSTROOM \\ E-pos: nvorster@telkomsa.net
}

\begin{abstract}
The imago Dei in protological, Christological and eschatological perspective

This article discusses the significance of the concept of the "imago Dei" for theological anthropology. Genesis 1 deliberately gives the concept an "open" meaning to make further theological reflection on the nature thereof possible. A purely protological understanding of the concept is therefore insufficient. The New Testament provides the "imago Dei" with a Christological and eschatological understanding that is essential for a correct understanding of the concept as well as for the development of a theological anthropology.
\end{abstract}

\section{Opsomming}

\section{Die imago Dei in protologiese, Christologiese en eskatologiese perspektief}

Hierdie artikel bespreek die belang van die konsep van die "imago Dei" vir teologiese antropologie. Die sentrale teoretiese argument van die artikel is dat Genesis 1 doelbewus 'n "oop" betekenis aan die "imago Dei" gee, sodat dit verder deur teologiese besinning ingevul kan word. Die "imago Dei" kan daarom nie alleenlik vanuit 'n protologiese perspektief verstaan word nie. Die Christologiese en eskatologiese inhoud wat die Nuwe Testament aan hierdie konsep gee, is bepalend vir die verstaan van die begrip en is belangrik vir die uiteindelike uitbou van 'n teologiese antropologie. 


\section{Inleidend}

Die Christelike dogmatiek neem bykans sonder uitsondering die konsep van die imago Dei as uitgangspunt vir sy leer oor die mens. Daar bestaan egter weinig eenstemmigheid onder teoloë oor die presiese inhoud en betekenis van die imago Dei. Die mens se beeldskap is byvoorbeeld deur die geskiedenis begrond in die mens se vrye wil, sy intellek en rasionele vermoëns; sy morele aard, sy selfbewussyn en onsterflike siel, sy emosionele eienskappe wat hom onderskei van diere; sy selftransendente aard, uiterlike voorkoms, sy verteenwoordiging van God op aarde, en sy verhouding met God (vgl. Towner, 2005:343). Hierdie verskillende interpretasies is grootliks daaraan te wyte dat die priesterlike skeppingsverhaal 'n vae definisie van die mens se beeldskap gee. Veral die multivalente (meerwaardig) gebruik van die begrippe sélém (gelykenis) en děmût (kopie) gee aanleiding tot verwarring en spekulasie. Ou-Testamentici is dit eens dat die konsep van die imago Dei slegs in die priesterlike dele van Genesis 1-11, wat 'n betreklike laat datering het, voorkom. Dit kan daarom volgens sommiges nie as 'n kerntema in die Ou Testament beskou word nie (vgl. Macdonald, 2008:304).

Die geldigheid van hierdie stelling hang egter van die inhoud wat aan die konsep gegee word af. Indien die Imago Dei wesensontologies as ingeskape eienskappe van die mens verstaan word - soos deur Irenaeus, Philo en Gregorius - is die konsep nie van sentrale belang in die Ou Testament nie. Indien dit egter ' $n$ relasionele begrip is wat die mens in ' $n$ verhouding tot God stel, of as dit 'n aanduiding is van hoe die mens God op aarde verteenwoordig, kan dit met stelligheid beweer word dat die Ou Testament die begrip van God se verhouding met die mens in die verbond goed uitdruk en saamvat. Towner (2005:350) wys tereg daarop dat alle bybelse antropologie uiteindelik teologiese antropologie is wat die mens in terme van sy verhouding tot God definieër. Hoewel die verwysing na die mens as beeld van God min in die Ou Testament voorkom, is die $\mathrm{Ou}$ Testament deurweef met die siening dat die mens alleen in terme van sy verhouding met God verstaan kan word.

Verder moet in gedagte gehou word dat die sistematiese teologie se belangstelling in die imago Dei grootliks te wyte is aan die Christologiese inhoud wat die Nuwe Testament aan die begrip gee. Die Nuwe-Testamentiese skrywers vind aansluiting by die priesterlike verhaal se beskrywing van die status van die mens en bou dit verder uit deur dit Christologies te begrond en eskatologies op die lewe van die kerk toe te pas. Volgens Grenz (2004:626) is die konsep van die imago Dei 'n sleutelmotief in die Nuwe-Testamentiese Christologie. 
Die Nuwe-Testamentiese skrywers gebruik dit om God se heilshistoriese werk in die mens van begin tot einde te verklaar. Die dogma van die imago Dei het daarom belangrike implikasies vir enige teologiese antropologie, hamartiologie en 'n Christelike begrip van heiligmaking.

Die doel van hierdie artikel is om 'n raamwerk aan 'n teologiese antropologie te gee, deur op die konsep van die imago Dei te fokus. Vir die doeleindes van die artikel is dit belangrik om 'n onderskeid tussen 'n teologiese antropologie en Christelike antropologie te maak. Die Skrif bied nie 'n uitgewerkte kosmologie of antropologie nie, maar gee die breë kontoere waarbinne 'n Christelike antropologie en kosmologie uitgebou kan word. Die doel van 'n teologiese antropologie is om hierdie breë kontoere te ondersoek en te beskryf. Die taak van die Christelike filosofie is om met die teologiese gegewens tot sy beskikking in gesprek met ander sosiale wetenskappe te tree en 'n Christelike antropologie op 'n interdissiplinêre grondslag uit te bou. Teologiese antropologie lê derhalwe op die vlak van die teologie, terwyl die uitbou van 'n Christelike antropologie die taak van Christelike filosofie is.

Die sentrale teoretiese argument van die artikel is dat die priesterlike verhaal doelbewus 'n "oop" betekenis aan die konsep van die mens se beeldskap gee, sodat dit verder deur teologiese besinning ingevul kan word. Die imago Dei kan daarom nie alleenlik vanuit 'n protologiese perspektief verstaan word nie. Die Christologiese en eskatologiese inhoud wat die Nuwe Testament aan die konsep gee, is bepalend vir die verstaan van die begrip en die uitbou van 'n teologiese antropologie. Terselfdertyd kan die Nuwe-Testamentiese omskrywing van die beeldskap nie na behore verstaan word sonder die protologiese begronding van die beeldskap in die priesterlike skeppingsverhaal nie. Daar kan immers nooit oor die mens se beeldskap gepraat word sonder om kennis te neem van God se oorspronklike doel met die mens se skepping nie.

\section{Die imago Dei in protologiese perspektief}

Genesis 1:26-28 bied verskeie interpretasiemoontlikhede vir die mens se beeldskap. Die beeldskap kan op grond van Genesis 1:26 aan die mens se verteenwoordiging van God verbind word. Die wisselende gebruik van děmût en sélém maak dit moontlik om hierdie verteenwoordiging te kwalifiseer as 'n reflektering van God se deugde (děmût), of om dit in ontologiese en fisieke eienskappe wat die mens met God sou deel (sélém), te soek. Děmût kom 21 keer in die $\mathrm{Ou}$ Testament voor en is ontleen aan 'n Hebreeuse wortelbete- 
kenis wat op 'n refleksie of kopie dui. Sélém kan met "gelykenis" vertaal word. Die woord word sewentien keer in die Ou Testament gebruik en dui in die meeste gevalle op 'n fisieke voorstelling. Die beeldskap kan egter ook na aanleiding van Genesis 1:27 aan die mens se geskapenheid as man en vrou verbind word. Indien vers 26 en 27 saam gelees word, kan die beeldskap daarin gesoek word dat die mens, soos God, 'n enkelvoudige en meervoudige bestaan voer. Dit is verder moontlik om op grond van vers 28 die beeldskap te soek in 'n verbinding van die mens se geskapenheid as man en vrou, en die opdrag om oor die skepping te heers. Elkeen van hierdie keusemoontlikhede is deur die geskiedenis gevolg.

\subsection{Verteenwoordigende sienings}

Irenaeus het op grond van die gebruik van die woorde děmût en sélém in Genesis 1:26-28 'n onderskeid getref tussen die mens se beeld van God in 'n natuurlike sin (imago) en bonatuurlike sin (similitudo). Imago dui op die mens se natuurlike vermoë tot vernuf en vryheid, terwyl similitudo op 'n bonatuurlike gelykenis van God dui. Die beeldskap bestaan volgens Irenaeus daarin dat die mens uiteindelik aan die goddelike natuur deel sal kry (vgl. Vorster, 2003:282). Die probleem met Irenaeus se begrip, is dat dit 'n sterk gnostiese invloed toon. Die gedagte dat die mens 'n fisieke afbeelding van God is, of aan die goddelike natuur deel kan hê, is strydig met die antropologie van die Ou Testament wat juis die onderskeid tussen God en mens probeer handhaaf. Die verbod wat die tweede gebod op die afbeelding van God plaas, asook die Ou Testament se assosiasie van sodanige aktiwiteite met heidense gebruike, is 'n duidelike weerspieëling hiervan.

Verskeie Ou-Testamentici verklaar sélém - in navolging van Von Rad in terme van die antieke Nabye Ooste se koninklike ideologie. Von Rad (1972:60) verduidelik hierdie teorie.

Just as powerful earthly kings, to indicate their claim to dominion, erect an image of themselves in the provinces of their empires where they do not personally appear, so man is placed upon earth in God's image as God's sovereign emblem. He is really only God's representative, summoned to maintain and enforce God's claim to dominion over the earth.

Die priesterlike skrywers sou volgens hierdie siening die koninklike ideologie oorgeneem en dit tot die ganse mensdom uitgebrei het (vgl. MacDonald, 2008:304). Bird (1981:140) wys tereg daarop dat die Ou Testament se gebruik van sélém - asook sy verstaan van 
koningskap - nie sodanige interpretasie ondersteun nie. Verder moet dit in gedagte gehou word dat die Ou Testament baie klem plaas op God se persoonlike teenwoordige betrokkenheid in die skepping. Hoewel die Ou Testament enige vorm van panteïsme verwerp wat die skeiding tussen God en sy skepping ontken, aanvaar dit ook nie 'n vorm van deïsme wat God en die skepping op 'n absolute wyse skei nie. Von Rad se siening het wel meriete in die sin dat die priesterlike skeppingsverhaal en ander gedeeltes in die Ou Testament tog 'n koninklike status aan die mens toeken, maar dan nie in terme van die Nabye Ooste se koninklike ideologie nie (vgl. ook Ps. 8).

Volgens Brunner (1939:92) gebruik die priesterlike verhaal die konsep van die mens se beeldskap om uitdrukking te gee aan die mens se formele wesenstruktuur. Die mens is 'n "releksie" wat terugverwys na "lemand anders" (Brunner, 1939:96). Hy word deur God geskape as 'n wese wat teenoor Hom staan. Hierdie verhouding word daarin gekenmerk dat God deur die Woord Homself aan die mens openbaar, en dat Hy terselfdertyd aan die mens die gawe van rasionaliteit gee om sy Woord te ontvang (Brunner, 1939:103). Die mens is nie alleen deur God geskep nie, maar is in God en vir God geskep. Die kern van die mens se kreatuurlike struktuur is vrye selfbepaling wat die grond van sy bestaan en sy kennis in God vind (Brunner, 1939:96, 97). Die mens is 'n vrye en verantwoordelike wese wat met die skepping die gawe ontvang om nie net te "wees" nie, maar te "mag wees". Hy is nie soos die dier 'n voltooide wese nie, maar 'n wese wat deur selfkennis en selfbepaling kan ontwikkel (Brunner, 1939:97, 98). Die vraag is of Brunner se begronding van die beeldskap in vrye selfbepaling werklik reg aan die teks van Genesis 1:26-28 laat geskied. Die dialektiese onderskeid tussen Ek en $U$ waarop sy redenasie van vrye selfbepaling gegrond is, is immers 'n moderne antropologies-filosofiese konsep wat vreemd aan die antieke priesterlike teks is.

Die beslissende vraag is: Waarom word děmût en sélém saam gebruik? Dit is moontlik dat die sagter uitdrukking, děmût, parrallel met die sterk uitdrukking, sélém, gebruik word om die mens se beeldskap van God op 'n sterk, maar tog genuanseerde wyse uit te druk. Die mens is 'n representasie van God, maar in die sin van refleksie, nie fisieke eendersheid nie. Die mens is nie die direkte beeld van God nie, maar beeld in sy heersing oor die skepping, ' $n$ afbeelding van God se koninklike heerskappy (vgl. Jenni \& Westermann, 1976: 560-561). 
Teenoor Brunner en die klassieke kerkvaders verwerp Barth die idee dat die mens se beeldskap in enige inherente kwaliteite van die mens of in 'n formele wesenstruktuur geleë kan wees. Dit sou daarop neerkom dat die mens se beeldskap van God geskei kan word van sy verhouding met God. Barth wil niks van 'n moontlik natuurlike aanknopingspunt tussen God en mens weet nie, want dit misken die omvang van God se reddende genade in Christus (Jónsson, 1988: 69). Aangesien die mens met die oog op Christus geskep is, is hy ook na die beeld van God geskape. Volgens Barth (1960:319) kan die mens nooit in isolasie van God en sy medemens verstaan word nie. Hy is 'n wese wat in ontmoeting leef. Hierdie ontmoeting is ' $n$ verbondsverhouding met God en sy medemens. In sy eksegese van Genesis 1:26-28, fokus Barth veral op die meervoudsvorm wat vir God gebruik word, en op vers 27 se verbinding van die mens se beeldskap aan sy geskapenheid as man en vrou. Op grond hiervan, kom hy tot die gevolgtrekking dat die mens se beeldskap daarin bestaan dat die $E k-U$-verhouding in die goddelike wese analogies in die mens gereflekteer word (vgl. Barth, 1960:245 e.v.). Soos die sprekende Ek in God se wese in relasie tot die goddelike $U$ staan, staan God in relasie tot die mens wat Hy as sy bondgenoot aanspreek. Hierdie Ek-U-relasie word in die kreatuurlike verwantskap tussen man en vrou voortgesit (vgl. Durandt, 1982:156). Soos die verhouding in die goddelike Wese deur differensiasie en gemeenskap gekenmerk word, is die mens wat as man en vrou geskape is, ' $n$ wese wat in jukstaposisie en konjunksie leef. Die mens is daarom ' $n$ relasionele wese wat 'n dialektiese bestaan voer, as manlik en vroulik, id en ego, 'n individuele, maar ook kollektiewe wese, egosentries, maar tegelyk self-transendent (vgl. Towner, 2005:345; Jónsson, 1988:73).

Barth se verstaan van die mens se beeldskap as 'n relasionele konsep het groot invloed in die protestantse tradisie gehad (vgl. Jónsson, 1988:67). Sy interpretasie van Genesis 1:26-28 is egter nie sonder probleme nie. Die vraag is (soos in die geval van Brunner) of Barth werklik die oorspronklike intensie van die priesterlike skrywer respekteer. Manipuleer Barth nie dalk die teks om sy dialektiese antropologie daaruit te konstrueer nie? Kan daar bloot op grond van die gebruik van die goddelike meervoudsvorm in vers 26 afgelei word dat God 'n wese is wat in differensiasie en gemeenskap leef? Kan uit die verwysing na die geskapenheid van die mens as man en vrou afleidings oor die dialektiese aard van menswees gemaak word? 
Moltmann gee, soos Barth, 'n relasionele inhoud aan die imago Dei deur Genesis 1:26 en 27 aan mekaar te verbind. Hy poog in sy definisie egter om die dialektiese onderskeidings van Barth te vermy, asook enige hiërargiese onderskeidings van afhanklikheid tussen skepsels wat in die kultuurmandaat begrond kan word. Moltmann soek die beeldskap in die enkelvoudigheid en meervoudigheid van God wat ook in die mens gevind word. Soos die verhouding binne die Drie-eenheid deur 'n differensiasie in verhoudings, asook verhoudings in differensiasie gekenmerk word, word die menslike bestaan deur pluriformiteit gekenmerk (Moltmann, 1985:223). Hoewel Moltmann erken dat die priesterlike verhaal nie 'n leer van die Drie-eenheid van God ontwikkel nie, meen hy tog dat die teks daarvoor oop is (Moltmann, 1985:224). Hy begrond sy siening in die meervoudige en enkelvoudige terme wat in Genesis 1:26 en 27 gevind word:

Gen 1:26: Kom ons (meervoud) maak die mens as ons beeld (enkelvoud), ons verteenwoordiger

Gen 1:27: As beeld van God het Hy die mens geskep, man en vrou (meervoud) het Hy (enkelvoud) hulle geskep.

Volgens Moltmann (1985:217-218) korrespondeer die enkelvoudige beeld van God in vers 26 met die interne pluraliteit van God, terwyl die meervoudige verwysing na die mens as man en vrou in vers 27 met die goddelike enkelvoud korrespondeer. Hoewel Moltmann se relasionele begronding van die beeldskap in vers 26 en 27 sekerlik waarheidselemente bevat, is sy eksegese om twee redes problematies. Eerstens lyk dit na geforseerde eksegese om die beeldskap trinitaries te begrond bloot op grond van die goddelike meervoud in Genesis 1:26. Moltmann se Christelik-dogmatiese verklaring van die teks is beslis nie in ooreenstemming met die priesterlike skrywer se oorspronklike doel met die begrip nie. Sodoende word die eiesoortige rykheid van die protologiese inhoud wat die priesterlike skrywer aan die beeldskap gee, nie verreken nie. Hoewel sommige OuTestamentici meen dat die priesterlike skrywer bloot in Genesis 1:26 die meervoud van majesteit gebruik, is die meeste kommentators dit eens dat hier van 'n goddelike beraadslaging gepraat word. Op verskeie plekke in die Ou Testament word verwys na God wat met die hemelwesens om sy troon beraadslaag (vgl. Towner, 2005:344; Von Rad, 1972:59; 1 Kon. 22:19-23; Job 1:6-2:6; Ps. 82). Dit is moontlik dat die goddelike meervoudsvorm hier gebruik word as ' $n$ teëwig om te verhoed dat die mens se beeldskap nie te direk na die wese van God herlei word nie. Volgens Von Rad (1972:58) is 
sodanige interpretasie waarskynlik omdat dieselfde tegniek in Genesis 3:22 gebruik word.

Die tweede probleem met Moltmann se eksegese is dat hy die mens se geskapenheid as man en vrou geïsoleerd wil sien van die opdrag in vers $28 \mathrm{om}$ te heers. Volgens hom is die opdrag om te heers ' $\mathrm{n}$ uitvloeisel van die mens se beeldskap, en nie deel van die beeldskap self nie (Moltmann, 1985:224). Hy wil die mens se geskapenheid as man en vrou bloot op die vlak van relasionaliteit verklaar, maar nie op die biologiese vlak van fertiliteit nie (vgl. Welker, 1999:67). Op hierdie wyse probeer hy om op 'n kunsmatige wyse 'n egalitaristiese inhoud aan die mens se beeldskap te gee, sonder hantering van die problematiek wat in vers 28 se opdrag om te heers, ter sprake kom.

Bird en Welker lees Genesis 1:27 in samehang met vers 28. Volgens Bird (1981:129 e.v.) hoort seksuele differensiasie en biologiese reproduksie tot die kern van die mens se beeldskap. Genesis 1:27 beskryf nie net 'n sosiale verhouding tussen man en vrou nie, maar ook 'n biologiese verhouding. Bird motiveer haar siening deur op die algemene androsentriese (manlike) aard van die priesterlike geskrifte te wys. Dit kom veral na vore in die geskrifte se samestelling van die genealogieë en voorskrifte met betrekking tot die beoefening van 'n kultus. Die biologiese kern van die mens se beeldskap word duidelik wanneer die mens se geskapenheid as man en vrou saam gelees word met die kultuuropdrag om te heers. Die mens moet reproduseer en vermeerder ten einde te heers. Onder heers (rádâ en kábash) verstaan sy 'n gewelddadige onderwerping. Juis in die vermeerdering en heersing deur gewelddadige onderwerping, word die mens se beeldskap van God duidelik.

Die waarde van Bird se analise is daarin geleë dat sy die biologiese sy van die mens se beeldskap verreken en Genesis 1:27 en 28 in samehang lees. Sy poog nie om soos Moltmann die hiërargiese onderskeidings wat Genesis 1:28 onderlê, weg te redeneer nie. Dit is egter 'n ope vraag of haar begrip van die teks nie deur ' $n$ feministiese agenda bepaal word nie. Die gewelddadige en magsgedrewe grondslag wat sy aan die mens se beeldskap gee, is nie in ooreenstemming met die breëre konteks van die priesterlike skeppingsverhaal nie. Hoewel die begrippe rádâ en kábash in ander Bybelgedeeltes op gewelddadige onderwerping dui, kom dit in die priesterlike verhaal binne die ruimte van paradyslike harmonie voor. Botterweck en Ringren $(1977,2: 336)$ wys daarop dat die begrip rádâ in Genesis 1 binne die konteks van bewaring gebruik word en as 'n handeling wat tot die voordeel van die skepping as sodanig dien. 
Hierdie gegewe impliseer nie dat rádâ en kábash geen gewelddadige betekenis binne die priesterlike verhaal het nie, maar die konteks versag wel die inhoud van die begrippe, sodat dit nie op 'n rigiede wyse geïnterpreteer kan word nie. Die opdrag om te heers word verder binne die konteks gegee dat die mens as beeld van God geskape is. Dit kan onmoontlik op 'n reg tot eksploïtasie dui, aangesien die mens se beeldskap juis benadruk dat die mens in verantwoordelikheid teenoor die Skepper moet optree.

Welker bied 'n meer genuanseerde perspektief op die verhouding tussen Genesis 1:27 en 28. Volgens Welker (1999:13) dui die begrip skepping in die skeppingsverhale op die konstruksie en onderhouding van assosiasies van interafhanklike verhoudings tussen verskillende kreatuurlike sfere. Die kultuurmandaat veronderstel 'n hiërargie van verhoudings tussen mens en dier. Hoewel mens en dier 'n gemeenskaplike omgewing deel, is diere wesens van 'n laer orde wat onderworpe aan die mensdom leef. Die priesterlike verhaal stel dit duidelik dat diere geensins 'n hoër status as mense kan geniet nie. Die mens as beeld van God staan teenoor diere. Terselfdertyd veronderstel die priesterlike skeppingsverhaal ook 'n gemeenskap van belange. Hoewel die verhouding tusen mens en dier hiërargies van aard is en 'n gewelddadige element bevat, besit dit ook 'n positiewe element. Eerstens staan die mens in 'n gemeenskap van solidariteit met diere, in die sin dat mens en dier dieselfde omgewing deel. Tweedens moet die mens, analogies aan die koninklike ideologieë van die antieke Ooste, sy heerskappy op 'n verantwoordelike wyse teenoor diere uitoefen en op 'n verantwoordbare wyse teenoor God (Welker, 1999:71). In die kultuurmandaat gaan dit oor die bewaring van die skepping ooreenkomstig sy komplekse strukture van interafhanklikheid, terwyl die belange van die mens eweneens vooropgestel word. Die mens moet die skepping bewaar en beskerm. Hy mag geweld gebruik, maar nie op 'n manier wat gemeenskap vernietig nie. Welker se verduideliking van die beeldskap is aantreklik, omdat hy erns maak met die teks se boodskap en nie moderne filosofiese kategorieë op die teks probeer afdwing nie. Verder verreken hy sowel die biologiese as die relasionele element in die beeldskap, en verreken hy die hiërargiese element wat in die begrippe rádâ en kábash geleë is.

\section{2 'n Moontlike hipotese}

In die lig van bogenoemde gesprek kan die volgende hipotese aangaande Genesis 1:26-28 se protologiese beskrywing van die mens se beeldskap gestel word. Genesis 1:26-28 gee 'n versigtige en oop 
betekenis aan die mens se beeldskap. Enersyds poog die teks deur die konsep van die mens se beeldskap om God en mens op mekaar te betrek. Andersyds stel die teks egter ook teëwigte in waardeur dit duidelik is dat daar 'n wesenlike verskil tussen God en die mens is. Die mens kan gevolglik nie te nóú op God betrek word nie. Hierdie teëwigte word aangebring deur die wisselende gebruik van děmǔt en sélém in vers 26 en die verwysing na die hemelse beraadslaging in vers 26. Die teks probeer nie soseer om 'n duidelike inhoud aan die beeldskap te gee nie (dit verskaf byvoorbeeld nie 'n wesensontologiese verklaring van die mens se synstruktuur nie), maar gee eerder 'n breë omskrywing van die gevolge van die beeldskap vir die menslike bestaan. Deur hierdie "oop" benadering van die teks word die moontlikheid vir 'n verdere toekomstige invulling van die inhoud van die mens se beeldskap geskep.

Die beeldskap het in Genesis 1:26-28 'n duidelike relasionele gerigtheid, maar dit bevat ook 'n definitiewe hiërargiese en biologiese komponent. Dit gaan in die priesterlike skeppingsverhaal oor die verhouding tussen God, mens en die kreatuurlike skepping en die roeping wat die mens ontvang. God en mens word op mekaar betrek, maar ook van mekaar onderskei; mens en dier word op mekaar betrek, maar ook van mekaar onderskei. Die verhouding tussen God, mens en dier word deur gemeenskap gekenmerk, maar is terselfdertyd hiërargies van aard. Anders as die dier, is die mens geskape om in 'n verhouding met God te leef. Hy verteenwoordig God op aarde, maar is nie God nie. Sy verteenwoordiging van God impliseer dadelik ook verantwoordbaarheid voor God. Die mens se taak is om God se deugde te reflekteer in die wyse waarop hy met die kreatuurlike sfere in God se skepping omgaan. Wat hierdie deugde presies inhou, laat die teks vir verdere invulling en besinning oop.

Net soos daar 'n hiërargiese element in die verhouding tussen God en mens bestaan, is die mens se verhouding tot die kreatuurlike hiërargies van aard. Sy geskapenheid as man en vrou dui enersyds op 'n biologiese potensiaal om te vermeerder en te heers, en andersyds op die sosiale vermoë om te kommunikeer en te kultiveer. Die mens is verhewe bo diere en het, anders as diere, die vermoë tot selfbewussyn en kommunikasie. Sy reg om oor die kreatuurlike sfeer te heers, is egter nie sinoniem met onbeperkte mag of 'n reg tot eksploïtasie nie. Dit is 'n heerskappy wat met plig gepaard gaan. Heerskappy deur eksploitasie impliseer dat die heerser sy eie wil uitvoer ten koste van die inherente regte van die sfeer waaroor hy regeer. Heerskappy wat met plig gepaard gaan, veron- 
derstel egter dat die heerser 'n oorkoepelende doelwit nastreef wat belangriker is as sy eie onmiddellike belange (vgl. Pannenberg, 2004:80). Dit gaan in Genesis 1 duidelik oor heerskappy wat met plig gepaard gaan. In sy heersing moet die mens verantwoordelik teenoor die Skepper optree. Hy moet die assosiasies van die verskillende kreatuurlike sfere bewaar en mag nooit die gemeenskap tussen die verskillende sfere vernietig nie.

\subsection{Sonde en beeldskap}

Binne die hoofstroomteologie is met enkele uitsonderings grootliks eenstemmigheid dat die sonde nie die mens se beeldskap vernietig het nie, maar wel verwring en verdraai het.

Die Reformasie het die vraagstuk oor die verhouding tussen die sonde en die mens se beeldskap op so 'n wyse probeer hanteer, dat daar nie 'n invalshoek vir die Arminianisme gelaat is nie. In die Lutherse tradisie is die beeldskap hoofsaaklik in verband met die mens se oorspronklike goedheid (iustitia originalis) gebring. Die sonde het gevolglik die mens se beeldskap heeltemal vernietig. Hoewel sowel Luther as die Formula Concordiae op hierdie manier oor die beeldskap praat, is sodanige siening nie konsekwent binne die Lutherse tradisie gehandhaaf nie (vgl. Berkouwer, 1957:43). Calvyn onderskei tussen die mens se natuurlike gawes wat bedorwe is en sy bonatuurlike gawes wat hom heeltemal ontneem is (vgl. Inst. 2.2.12). Die natuurlike gawes bestaan uit die wil, verstand en oordeelsvermoë. Hierdie gawes is bedorwe, maar nie heeltemal vernietig nie, omdat dit wesenlik tot die menslike natuur is. Daar bestaan nog skitterende vonkies wat aandui dat die mens van diere verskil (Calvyn, 1986 [1559] Inst. 2.2.12). Die bonatuurlike gawes bestaan volgens Calvyn uit geloof, liefde, geregtigheid en heiligheid. Hierdie gawes is heeltemal vernietig en kan alleenlik deur die weergeboorte herwin word (Calvyn, 1986 [1559] Inst. 2.2.12). Deur te praat van oorblyfsels van die mens se beeldskap wat in hom oorbly, ontken Calvyn nie die totale verdorwenheid van die mens nie. Vir Calvyn dui die mens se totale verdorwenheid nie daarop dat die mens ontmenslik word, of ophou om mens te wees nie, maar wel dat alle dele van menswees deur die sonde aangetas word. Die Nederlandse Geloofsbelydenis (NGB art. 14) en Dordtse Leerreëls sluit by Calvyn se gebruik van die term oorblyfsel (vestigia) aan. Volgens die NGB (art. 14) bly daar na die sondeval oorblyfsels van die mens se oorspronklike gawes oor. Hierdie vestigia relativeer egter nie die totale verdorwenheid van die mens nie, maar intensifiseer eintlik die menslike toestand van sonde, omdat dit 'n aandui- 
ding is dat daar vir die mens geen verontskuldiging kan wees nie. Die Dordtse Leerreëls (art. 3/4:4) praat van 'n "lig van die natuur" wat in die mens oorgebly het, maar wat nie genoegsaam vir saligheid is nie. Die gereformeerde belydenisskrifte gebruik nie die konsep van "oorblyfsels van goedheid" om die mens se sondige toestand as 'n gedeeltelike korrupsie te beskryf nie, maar wel om die volle erns van die mens se skuld voor God, asook die mens se verantwoordbaarheid teenoor God, duidelik te laat blyk.

Die gereformeerde teologie ná die Reformasie het - in die voetspoor van die gereformeerde belydenisskrifte - dikwels tussen die mens se beeldskap in 'n ruimer en engere sin onderskei (vgl. Berkouwer, 1957:35). In die ruimer sin beteken die beeldskap dat die sonde die mens nie verdierlik of demoniseer nie, maar dat God die mens nog steeds as mens handhaaf. Tog verloor die mens die beeldskap in 'n enger sin, deurdat die mens sy gemeenskap met God verloor asook die gawes van kennis, geregtigheid en heiligheid.

Die sienings van Barth, Thielicke en Brunner verdien vermelding, omdat dit in die twintigste-eeuse teologie 'n besondere invloed uitgeoefen het. Barth (1960:31 e.v.) meen dat die beeldskap van die mens nie op 'n bepaalde eienskap dui nie, maar op die mens se bestemming. Dit beteken dat die beeldskap nie verlore kan gaan nie, want waarvoor die mens bestem is en wat hy/sy nog nie besit nie, kan hy/sy nie verloor nie. Uiteraard beteken dit volgens Barth nie dat die beeldskap ' $n$ blote toekomstige belofte is nie, want die belofte vind sy vervulling in Jesus Christus - in Wie die eerste mens geskape is (vgl. Durandt, 1982:157). Die implikasie van Barth se standpunt is dat Christus nie aan die mens se natuur deelkry nie, maar die mens aan Christus se natuur. Die verwantskap tussen God en mens is vir Barth 'n genadeverhouding. Die mens is met die oog op Christus geskape. Die vraag is egter of Barth hierdeur nie God die oorsprong van sonde maak nie? As God die wêreld skep sodat Hy Christus kan stuur, impliseer dit tog dat Hy die sonde wil, selfs al is dit net 'n toelatende wil. Die Skrif self volg nie Barth se objektivistiese benadering nie, maar begrond die noodsaak vir Christus se koms in die toestand van sonde.

Brunner (1939:95-96) poog om weg te beweeg van die Reformasie se gedagte van 'n "res" van goedheid wat in die mens agterbly, die Roomse onderskeiding tussen die mens se natuurlike en bonatuurlike beeld en die radikale siening dat die humanum 'n profanum geword het. Hy onderskei tussen die mens se formele en materiële beeld. Deur hierdie onderskeidings poog Brunner om 'n legitieme vorm van natuurteologie te skep (Jónsson, 1988:70). Die 
formele dui op die mens se vorm en struktuur, sy humanitas, wat onverliesbaar is (Brunner, 1939:170). Die mens het immers nog steeds sy ratio waardeur hy die Woord van God kan ontvang. Sy modus van bestaan verander egter vanaf 'n bestaan in liefde, tot 'n bestaan onder die wet en oordeel van God (Brunner, 1939:103). Hierteenoor dui die materiële beeld op die eienskappe van die mens wat verlore gegaan het deur die sonde, maar wat deur die genade van God weer aan die mens geskenk kan word. Die vraag is of Brunner se klem op die ratio van die mens wat, ondanks die sonde 'n aanknopingspunt tussen God en mens vorm, genoegsaam die totale verdorwenheid van die mens verreken.

Volgens Thielicke (1966:159 e.v.) dra die mens se beeldskap van God 'n onuitwisbare karakter, omdat die beeldskap daarin bestaan dat God met die mens in verhouding tree. Hoewel die mens se beeldskap 'n ontiese sy het, word die mens nie deur sy ontiese eienskappe gekarakteriseer nie. Die beeldskap kan nie van gemeenskap met God losgemaak word nie. Selfs na die sondeval staan die mens nog steeds in verhouding met God - selfs al is die verhouding negatief van aard. Deur die sonde het die mens die beeldskap slegs in die sin van 'n positiewe verhouding met God verloor. In Christus word dit egter weer herstel. Die waarde van Thielicke se siening is daarin geleë dat hy insien dat die mens nie van God losgemaak kan word nie. Die vraag is egter of hy nie die mens se beeldskap in relasie laat opgaan nie. Hoewel die mens se beeldskap 'n sterk relasionele inhoud het en daarop dui dat die mens se wese deur sy verhouding met God bepaal word, is die beeldskap nie 'n verhouding nie, maar die beeldskap handel oor die mens in sy totaliteit.

Die protologiese geskiedenis in Genesis 1-11 handhaaf duidelik die mens se beeldskap na die sondeval. Verwysings na die mens as beeld van God kom steeds voor in die ná-sondeval narratiewe (Gen. 5:1b-2; 9:6). In Genesis 9 word die opdragte van Genesis 1 aan die mens weer herhaal. Genesis 9:6 meld spesifiek dat daar iets onaantasbaars in die mens is, want nie die mens of die dier mag hom aan die lewe van die mens vergryp nie. In die Nuwe Testament word die mens se beeldskap nêrens as verlore beskryf nie. Inteendeel, in Jakobus 3:9 word die beeldskap in verband gebring met die feit dat die mens deur God geskape is en daarom nie gevloek of haatdraend behandel mag word nie (vgl. ook 1 Kor. 11:7). Die

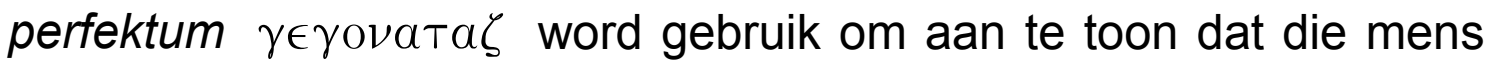
se gelykenis van God nog steeds van krag is. 
Die feit dat die mens se beeldskap nie deur die sonde vernietig word nie beteken nie dat die sonde die mens net gedeeltelik beïnvloed nie. Dit gaan eerder daaroor dat God die mens ten spyte van die sonde nog steeds as mens handhaaf. Berkouwer (1957:140) wys tereg daarop dat daar 'n onderskeid tussen die menslike natuur en sonde getref moet word. Die sonde woon in die menslike natuur, maar is nie die menslike natuur self nie. Selfs na die sondeval bly die mens 'n opus et creatura Dei. Juis daarom kan Christus die menslike natuur aanneem. Sonde verwring en verdraai die mens se beeldskap van God, maar vernietig nie die mens se verhouding met God, sy medemens en die wêreld nie. Indien die relasionele raamwerk van die mens se lewe verwoes word, sou die mens ophou bestaan. God handhaaf die mens nog steeds as mens - ondanks die sonde (vgl. Smail, 2003:26). Indien die mens se beeldskap heeltemal verlore sou gaan, sou dit moontlik wees om die mens van alle reg tot waardigheid te ontneem.

\section{Die imago Dei in Christologiese perspektief}

Die Genesis-weergawe van die mens se beeldskap verskaf die breë buitelyne vir begrip van die mens se verhouding met God. Terselfdertyd word die uitbreiding van die konsep oopgelaat vir verdere besinning. 'n Teologiese antropologie kan daarom nie met 'n protologiese benadering tot die mens se beeldskap volstaan nie. Die Christologiese grondslag wat die Nuwe Testament aan die konsep gee, is van uiterste belang vir die verdere uitbreiding van die konsep - spesifiek met betrekking tot die bestemming van die mens.

Die Nuwe Testament bevat 'n duidelik imago Dei-Christologie. In 'n sekere sin gebruik die Nuwe-Testamentiese skrywers die oop betekenis wat die priesterlike skrywer aan die mens se beeldskap gee om die inhoud van die beeldskap verder in die lig van die koms van Jesus Christus uit te brei. Jesus Christus word as die vervulling van God se oorspronklike doel met die mens gesien. In Hom word die bestemming van die mens se beeldskap duidelik.

Sommige tekste in die Nuwe Testament verwys spesifiek na Jesus as die volmaakte beeld van God, terwyl ander tekste die glorieteologie van die Ou Testament op Christus van toepassing maak. In 2 Korintiërs 4:4 en 6 word Christus die $\epsilon \hat{i} \kappa \hat{\nu} \nu$ Tôे $\theta \in \mathrm{o} \hat{v}$ genoem wat

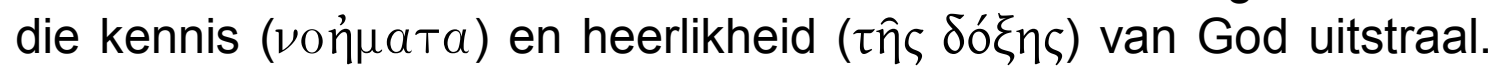
Eı $\omega \nu$ is 'n Griekse vertaling van sélém. Dit dui op 'n perfekte refleksie van 'n oorspronklike prototipe. Grenz (2004:619) wys verder daarop dat $\epsilon \iota \kappa \omega \nu$ op meer as 'n afbeelding dui. Die $\epsilon \iota \kappa \omega \nu$ is ook 'n 
deelnemer van die realiteit wat dit afbeeld. Christus is volgens 2 Korintiërs 4 en 6 meer as 'n refleksie van God. Hy is 'n manifestasie van God wat die heerlikheid van God uitstraal. God se wese en karakter word op 'n volmaakte wyse in die lewe van Christus gereflekteer.

Christus is volgens die Nuwe Testament nie bloot die manifestasie van God nie, maar ook die toonbeeld van die ware mens. Paulus gebruik duidelik in 2 Korintiërs 4 die priesterlike verhaal se konsep van die mens as beeld van God om aan te toon dat Jesus die tweede Adam is. Christus is die begin van die nuwe mensheid en terselfdertyd die bestemming van die oorspronklike mensheid. Hy is die anti-tipe van Adam (vgl. Rom. 5). Deur Christus se beeldskap in verband te bring met sy hoofskap oor sy liggaam - die kerk - word die imago Dei ook binne 'n sosiale perspektief geplaas. Christus se beeldskap het implikasies vir die sosiale struktuur van die nuwe mensheid.

In Kolossense 1:15-20 word Christus se beeldskap van God gebruik om 'n kosmologiese inhoud aan Christus se heerskappy te gee. Christus is nie net Middelaar in 'n soteriologiese sin (dogma/leerstelling van verlossing) nie, maar $\mathrm{Hy}$ is Skeppingsmiddelaar wat bokant die geskiedenis vanuit die hemel regeer (vgl. Standhartinger, 1999:206). Die tema van heersing in Genesis 1 word spesifiek verder uitgebou en ingevul. In Genesis 1 ontvang die mens die mandaat om oor die kreatuurlike te heers. Christus wat die ware beeld van God is, kry egter op grond van sy versoeningswerk die mandaat om oor die hele kosmos te heers. Christus se heerskappy straal die heerlikheid van God op 'n meer glorieryke wyse uit as die mens. Christus is nie net 'n afbeelding van God nie, maar $\mathrm{Hy}$ is die volle beeld van God (MacDonald, 2000:58). Kolossense 1:15 en 18 verbind Jesus se beeldskap spesifiek aan die feit dat Hy die $\pi \rho \omega т$ т́токо $\varsigma$ is - die eersgeborene van die skepping en die eersgeborene uit die dood. Volgens Macdonald (2000:58) dui hierdie term nie net op die orde van oorsprong nie, maar ook op die orde van belangrikheid. Deur middel van hierdie term word na die oorspronklike skepping terugverwys en na die nuwe skepping vooruitgewys. Christus was (in 'n baie meer glorieryke sin as Adam) van die begin af beeld van God en die eersgeborene van elke geskapene. Christus is tegelykertyd die oorsprong van die nuwe skepping wat die eerste skepping vervang - waarvan Adam die verteenwoordiger is. 
Benewens 2 Korintiërs 4 en Kolossense 1 wat spesifiek na Christus as die volmaakte beeld van God verwys, is daar ook tekste wat die glorieteologie van die Ou Testament op Christus van toepassing maak. ' $n$ Kenmerk van hierdie gedeeltes is dat dit die status van glorie, wat deur die priesterlike skeppingsverhaal en ander Ou-Testamentiese gedeeltes soos Psalm 8 aan die mensdom as geheel toegeken word, verskuif na die Persoon van Jesus wat verteenwoordiger van die nuwe mensheid is. Hebreërs 2:6-9 haal byvoorbeeld uit Psalm 8 aan om aan te toon dat dit die mens se bestemming is om oor alles te regeer. Hierdie Ou-Testamentiese belofte word waar in Jesus Christus, aan wie alle dinge onderwerp word op grond van sy lyding en dood. Op hierdie wyse word Psalm 8 se universele antropologie op Christus van toepassing gemaak. Hebreërs 1:1-3 is 'n verdere voorbeeld waar Christus se beeldskap direk aan sy koningskap verbind word. Hy is die ewebeeld van God wat die heerlikheid van God uitstraal. Deur sy oorwinningswerk in sy kruisiging en opstanding vervul hy sy rol as die Beeld van God en voltooi hy die roeping van die mensheid. Gevolglik ontvang Hy die reg om oor alle dinge te regeer.

Volgens Smail (2003:27 e.v.) is die implikasie daarvan dat Christus God afbeeld en dat die imago Dei trinitaries verstaan moet word. Jesus Christus beeld sy Vader af en manifesteer die Heilige Gees. Die mens is slegs ' $n$ ware beeld van God indien hy die deugde van die verhouding tussen die Vader, Seun en Heilige Gees in sy lewe manifesteer. Smail gaan voort om die imago Dei in die lig van die perochetiese verhouding tussen die Vader, Seun en Heilige Gees te beskryf. Die mens se liefde moet iets manifesteer van die inisiërende liefde van God die Vader, die responskarakter van Christus se liefde, en die manifesterende aard van die Heilige Gees se liefde. Die Imago Dei is volgens Smail tegelykertyd Imago Trinitatis.

Die probleem met 'n trinitariese benadering is egter dat die Nuwe Testament self nie die beeldskap direk op 'n trinitariese wyse probeer begrond nie, maar alleenlik Christologies. 'n Trinitariese benadering skep oneindige moontlikhede vir kreatiewe spekulasie. Die wesensverhouding tussen die Drie-eenheid is ' $n$ verborgenheid waaroor die Skrif nie duidelike lig bied nie, en wat nie binne die begripsvermoë van die mens lê nie. Die mens kan nooit soos Christus die wese van God beliggaam nie. Daar is dus ' $n$ bepaalde diskontinuïteit tussen die beeldskap van Christus en dié van die mens. Hoewel die mens tot 'n mate God se deugde kan reflekteer, is daar ook deugde wat die mens, vanweë die wesenlike verskil tussen God en die mens, nie kan reflekteer nie. 


\section{Die imago Dei in eskatologiese perspektief}

Die Nuwe Testament gee nie slegs 'n Christologiese inhoud aan die imago Dei nie, maar bring ook die konsep in verband met die ontstaan en bestemming van 'n nuwe mensheid. Christus se koms na die aarde is 'n eskatologiese gebeurtenis. Hy reflekteer God se ware doel met die mens en in Hom - die volmaakte beeld van God word die beeldskap stelselmatig deur die Heilige Gees in die mens herstel. Hoewel alle mense opgeroep word om aan die beeld van Christus gelykvormig te word, word nie alle mense se beeldskap in Christus herstel nie. Die herstel van die beeldskap is 'n eskatologiese gawe van God aan sy uitverkore kinders. In Romeine 8:29-30 wys Paulus daarop dat slegs die uitverkorenes deur die Vader bestem is om gelykvormig te word aan die beeld van sy Seun (Vorster, 2003:326). Die herstel van die beeldskap word in hierdie verse spesifiek verbind aan God se uitverkiesing, die roeping van die mens, die vryspraak en die heerlikmaking. Vir 'n teologiese antropologie is die Nuwe Testament se teosentriese fundering van die herstel van die mens se beeldskap van die uiterste belang. Die mens is nie 'n outonome wese wat sy eie heil kan bewerk nie. Uit en in homself kan die mens nie bestaan nie. Hy kan alleenlik sy ware mensheid terugvind indien sy verhouding met God herstel word. Die mens se afhanklikheid van God is so radikaal dat hy nie in staat is om sy verhouding met God self te herstel nie. Die inisiatief kom van God. Dit is in ooreenstemming met die protologiese begronding wat die priesterlike verhaal aan die beeldskap gee. Die mens is 'n wese wat op God gerig is, van God afhanklik is, deur sy verhouding met God gedefinieër word en sy ware bestemming in God vind.

In 2 Korintiërs 3:18 word die herstel van die mens se beeldskap aan die werk van die Heilige Gees verbind. Die herstel van die beeldskap is 'n eskatologiese gawe wat in die hede begin, maar eers in die toekoms voltooi sal word. Die sentrale woord in 2 Korintiërs 3:18 is die passiewe werkwoord $\mu \epsilon \tau \alpha \mu \rho \rho \phi o u ́ \mu \epsilon \theta a$. Dit dui op 'n innerlike verandering in die mens wat deur God teweeggebring word sodat die mens 'n nuwe gestalte of gedaante sal vertoon. Christus is die oriëntasiepunt en einddoel van die verandering, aangesien die $\mu \in T \alpha \mu о \rho \phi о u ́ \mu \epsilon \theta \alpha$ in ooreenstemming met die beeld van Christus

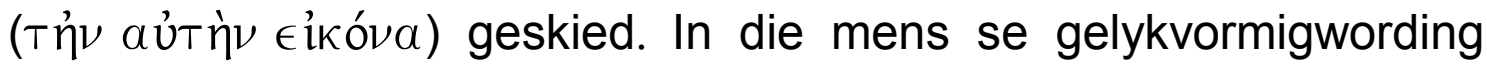
aan Christus gaan dit nie in die eerste plek oor 'n uitstraling van Christus se deugde nie. Dit gaan eerder oor 'n regte verhouding met God - ooreenkomstig die wil van God - wat deur Christus moontlik gemaak word. 
Die teologiese implikasie is dat die eskatologiese bestemming van die mens duidelik word in die beeld van Christus. Volgens 2 Korintiërs 3:18 word die mens van heerlikheid tot heerlikheid (’̊m ò $\delta o ́ \xi n \varsigma \in i \zeta \delta o ́ \xi \alpha \nu)$ getransformeer na die beeld van Christus. Hiermee word nie bedoel dat die mens vergoddelik word nie. Dit gaan in hierdie woorde oor ' $n$ weerspieëling van die heerlikheid van Christus, nie 'n mistieke eenwording nie. Die transformering na die beeld van Christus is ' $n$ voortdurende proses van een stadium na 'n ander wat steeds toeneem en wat uiteindelik op die voleinding uitloop (vgl. Vorster, 2003:326).

In Efesiërs 4:10 en Kolossense 3:10 word die inhoud van die herstelde beeldskap aan spesifieke kwaliteite verbind. Hierdie kwaliteite is goddelike gawes wat die mens in staat stel om sy ware bestemming te vind. Kolossense 3:10 verbind die herstelde beeldskap aan kennis ( $\left.\boldsymbol{c}^{\prime} \hat{\gamma} \gamma \nu \omega \sigma \iota \nu\right)$. Dit dui op 'n begrip van God se wil wat in 'n intieme gemeenskap met God sigbaar word (vgl. Louw \& Nida,

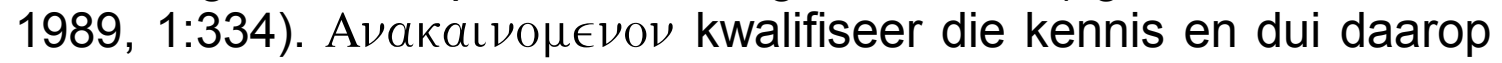
dat begrip van God se wil deur Hom geskenk word. Dit kan nie langs die weg van die menslike rede gevind word nie. Efesiërs 4:24 verbind die mens se beeldskap aan geregtigheid (

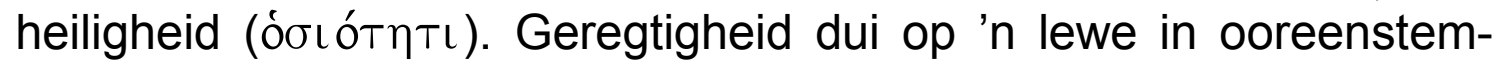
ming met die wil van God, terwyl heiligheid op 'n innerlike ingesteldheid in ooreenstemming met die wil van God dui (vgl. Louw \& Nida, 1989, 2:744-745). Bovermelde Pauliniese tekste verbind die herstelde beeldskap dus ten nouste aan die wil van God. Kennis is begrip van God se wil, geregtigheid is 'n lewe ooreenkomstig God se wil, en heiligheid is ' $n$ innerlike ingesteldheid ooreenkomstig die wil van God.

Die ontstaan van die nuwe mensheid vorm die klimaks van die heilshistoriese geskiedenis van die mens. Dit is die vervulling en uiteindelik definiërende moment van die imago Dei-konsep wat in Genesis gevind word. Die Adam-Christus-tipologie wat in verskeie Pauliniese tekste gevind word, dui daarop dat die skepping van Adam nie God se volle bedoeling vir die mens omvat nie. God se doel met die mens word eers volkome gerealiseer in die ontstaan van die nuwe mensheid en hulle deelname aan die geestelike liggaam van die tweede Adam (vgl. Grenz, 2004:623).

Die eskatologiese inhoud wat die Nuwe Testament aan die mens se beeldskap gee, impliseer dat die menslike geskiedenis teleologies (doelmatigheid van skepping) van aard is. Volgens die Skrif het die menslike geskiedenis 'n koherente vorm van 'n goddelike oorsprong, 
'n soteriologiese (salvation) kern in die sterwe en opstanding van Christus en 'n eskatologiese einde. Webster (2000:21) wys tereg daarop dat die Skrif se klem op die teleologiese aard van die menslike geskiedenis onderskei moet word van 'n "futurisme" wat 'n koherente narratiewe skema vir die menslike geskiedenis deur voorspellings oor uitkomste probeer ontwikkel. Die Christelike eskatologie het nie 'n tegniese karakter nie, maar is inherent Christologies. Dit het die Persoon van Christus as basis en inhoud. Die skepping se geskiedenis ontplooi op 'n doelmatige wyse as gevolg van die wending wat Christus se koms gebring het. Hierdie teleologiese georiënteerdheid van Christelike eskatologie veronderstel dat die mens se bestaan doelmatig, sinvol en hoopvol kan wees. Die Christelike hoop is egter nie utopies van aard in die sin dat die mens sy eie heil kan bewerk nie. Dis ook nie gebaseer op projeksies van uitkomste nie, maar bestaan in 'n gelowige aanvaarding van God se beloftes wat op 'n moreel-etiese lewe uitloop wat die wêreld transformeer. Die teenstrydighede in die geskiedenis word uiteindelik nie binne die geskiedenis opgelos nie, maar op die vlak van die ewige en die Goddelike (vgl. Niebuhr, 1943:47).

\section{Konklusie}

Uiteraard kan 'n teologiese antropologie nie slegs op die fondament van die imago Dei uitgebou word nie. So 'n benadering sal reduksionisties wees en die ryke diversiteit van antropologiese perspektiewe in die Skrif misken. Elke loci in die Christelike dogmatiek, asook ander kerntemas in die Skrif (soos die verbond, koninkryk, ens.), bevat elemente wat vir 'n teologiese antropologie van belang is. Desnieteenstaande is die imago Dei van deurslaggewende belang vir 'n teologiese antropologie. Die volgende aspekte van die imago Dei kan, myns insiens, vrugbaar gebruik word om 'n teologiese antropologie uit te bou wat breë kontoere vir die ontwikeling van 'n Christelike antropologie kan stel. Ter wille van bondigheid word met enkele slotopmerkings volstaan.

\section{Die mens is 'n religieuse wese}

Die mens is 'n religieuse wese, geskape deur God om in sy diens te leef. Die mens is in sy wese transendent. Sy lewe wys buite homself heen na God, wat die grond van die mens is en ook sy bestemming bepaal. God het die mens religieus geskape - met ander woorde op Hom gerig - en die mens kan hierdie religiositeit nie ontsnap nie. In die uitbou van 'n teologiese antropologie moet dus eers God gesê word voordat mens gesê word (vgl. Durandt, 1982:139). Die weg 
moet vanaf die teologie na die antropologie loop en nie andersom nie, want die mens kan alleenlik in Christus, as die bron van kennis aangaande die mens, geken word.

\section{Die mens is 'n sondige wese}

Die kern van die sonde is daarin geleë dat die mens sy geskape gerigtheid op God probeer ontsnap, en poog om homself van God los te maak. Die invloed van die sonde op die mens is totaal en kleef aan alle aspekte van menswees. Menswees en sonde is daarom onlosmaaklik aan mekaar verbonde. 'n Volmaakte analise van die menslike natuur is onmoontlik, aangesien sonde ware selfkennis onmoontlik maak. Tog demoniseer of verdierlik die sonde nie die mens nie. Sonde woon in die menslike natuur, maar sonde is nie die menslike natuur nie. Die mens bly beeld van God. Tog lei die sonde daartoe dat die mens nie van die begin ' $n$ klaargemaakte beeld van God is nie. Die mens het 'n geskiedenis wat hy deurloop en kan alleen sy ware humaniteit in verbondenheid met God verwerklik.

\section{Die mens is 'n geestelike en biologiese wese}

Die mens is volgens die skeppingsverhale 'n geestelike wese wat sy gees van God ontvang (nefesh), en is daarom in staat om 'n selftransendente bestaan te voer. Terselfdertyd is die mens ook ' $n$ biologiese wese wat met ander kreatuurlike wesens dieselfde omgewing deel. Die verhouding tussen mens en dier is, soos die verhouding tussen God en mens, hiërargies van aard. Die imago Dei dui daarop dat die mens 'n hoër waardigheid as die dier besit. Die mens se reg om oor die kreatuurlike sfeer te heers, is egter nie onbeperk nie, maar korreleer met die plig om verantwoordelik teenoor die Skepper op te tree. Die mens mag nooit die gemeenskap tussen die verskillende kreatuurlike sfere vernietig nie, maar moet juis die delikate gemeenskap van kreatuurlike verhoudings in die skepping bewaar.

\section{Die mens is 'n relasionele wese}

Die mens is geskape om in 'n verhouding met God, die skepping, sy medemens en homself te leef. Die relasionele aard van die mens veronderstel dat die mens ' $n$ vrye en verantwoordelike wese is wat in verantwoordbaarheid teenoor God leef. Weens die in sonde gevallenheid van die mens en die gevolglike gebrokenheid van sy verhoudings, kan die mens nie afsonderlik van God en sy verlossingshandelings bestaan nie. Alleen God maak die herstel in die 
mens se verhoudings moontlik. Christus is die volmaakte Beeld van God, die oriënteringspunt en voorbeeld wat nagevolg moet word ten einde gebroke verhoudings te herstel.

\section{Die mens is 'n eskatologiese wese}

Die eskatologie het tweërlei implikasies vir 'n teologiese antropologie. Eerstens is die mens objek van God se genade. Sentraal tot menslike identiteit is die wederbarende werking van God, wat die mens nuut maak op grond van die versoeningswerk van Christus deur die werking van die Heilige Gees. Die mens kan op grond van die versoeningswerk van Christus, sin in sy bestaan vind en is nie aan bestaansangs oorgegewe nie. Tweedens is die menslike bestaan teleologies van aard omdat sy bestaan met God se eskatologiese bestemming vir die skepping saamhang. Die Skrif veronderstel nie tyd in sikliese terme nie, maar in liniêre terme as ' $n$ voortdurende beweging waarin God sy wil aan die mens openbaar, en die geskiedenis na sy bestemming laat afloop (vgl. Childs, 1978: 101). ' $n$ Teologiese antropologie sal gevolglik morele en etiese aangeleenthede hanteer binne die raamwerk van die teleologiese ontwikkeling van skepping, sondeval, verlossing en eskatologie. Menslike gedrag vind binne 'n vasgestelde orde plaas en moet in die lig van die godgegewe orde beoordeel word. Hierdie teleologiese begrip van die menslike geskiedenis, staan teenoor 'n postmoderne geskiedenisbeskouing wat die geskiedenis beskou as konstant-veranderlik en eindigend.

\section{Geraadpleegde bronne}

BARTH, K. 1960. Church dogmatics. Vol. 3(2): The doctrine of creation. Ed. by G.W. Bromiley \& T.F. Torrance. Edinburgh: Clark.

BERKOUWER, G.C. 1957. Dogmatische studien: de mens het beeld Gods. Kampen: Kok.

BIRD, P. 1981. "Male en female He created them": Gen 1:27b in the context of the priestly account of creation. Harvard theological review, 74:129-155.

BOTTERWECK, J.G. \& RINGGREN, H. 1977. Theological Dictionary of the Old Testament. Trans. by J.T. Willis. Grand Rapids: Eerdmans.

BRUNNER, E. 1939. Man in revolt: a Christian anthropology. Trans. by $\mathrm{O}$. Wyon. London: Lutterworth.

CALVYN, J. 1986 [1559]. Institusie van die Christelike godsdiens. Vert. deur H.W. Simpson. Potchefstroom: Calvyn Jubileumboekefonds.

CHILDS, J.M. 1978. Christian anthropology and ethics. Philadelphia: Fortress.

DURANDT, J.J.F. 1982. Skepping, mens en voorsienigheid. Pretoria: NG Kerkboekhandel. 
GRENZ, S.J. 2004. Jesus as the imago Dei: image of God Christology and the non-linear linearity of theology. Journal of the Evangelical Theological Society, 47(4):617-628.

JENNI, E. \& WESTERMANN, C. 1976. Theologisches Handwörterbuch zum Alten Testament. München: Kaiser.

JÓNSSON, G.A. 1988. The image of God: Genesis 1:26-28 in a century of Old Testament research. Uppsala: Almqist \& Wiksell. (Coniectanea Biblica. Old Testament Series 26.)

LOUW, J.P. \& NIDA, E.A. 1989. Greek-English Lexicon of the New Testament based on semantic domains. Volumes $1 \& 2$. New York: United Bible Societies.

MACDONALD, M.Y. 2000. Sacra Pagina. Vol. 17: Collosians, Ephesians. Minnesota: The Liturgical Press.

MACDONALD, N. 2008. The imago Dei and election: reading Genesis 1:26-28 and Old Testament scholarship with Karl Barth. International journal of systematic theology, 10(3):303-327.

MOLTMANN, J. 1985. God in creation: a new theology of creation and the Spirit of God. Trans. by M. Kohl. San Francisco: Harper \& Row.

NIEBUHR, R. 1943. The nature and destiny of man: a Christian interpretation. Vol. 2. London: Nisbet.

PANNENBERG, W. 2004. Anthropology in theological perspective. Trans. by M.J. O'Connel. London: Clark International.

SMAIL, T.A. 2003. In the image of the triune God. International journal of systematic theology, 5(1):22-32.

STANDHARTINGER, A. 1999. Studien zur Entstehungsgeschichte und Intention des Kolosserbriefs. Brill: Leiden.

THIELICKE, H. 1966. Theological ethics. Vol. 1. Trans. \& ed. by W. Lazareth. Philadelphia: Fortress.

TOWNER, W.S. 2005. Clones of God: Genesis 1:26-28 and the image of God in the Hebrew Bible. Interpretation: 341-356, Oct.

VON RAD, G. 1972. Genesis: a commentary. Rev. ed. London: SCM.

VORSTER, N. 2003. Kerk en menseregte binne 'n regstaat. Potchefstroom: Potchefstroomse Teologiese Publikasies.

WEBSTER, J. 2000. Eschatology, anthropology and postmodernity. International journal of systematic theology, 2(1):13-28.

WELKER, M. 1999. Creation and reality. Minneapolis: Fortress.

\section{Kernbegrippe:}

Christologie

eskatologie

imago Dei

protologie

\section{Key concepts:}

Christology

eschatology

imago Dei

protology 